\title{
Lead toxicity among working children and adolescents in Alexandria, Egypt
}

\author{
A. Zaki,' M. El-Shazly, ${ }^{1}$ M. Abdel-Fattah,' K. El-Said ${ }^{2}$ and F. Curtale ${ }^{3}$
}

$$
\begin{aligned}
& \text { التسمـم بالر حاص بين الاطفال والمراهقين العاملين في الإسكنلدرية، مصر }
\end{aligned}
$$

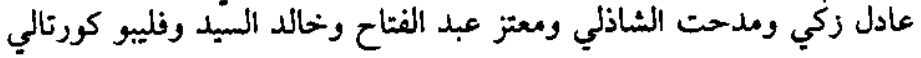

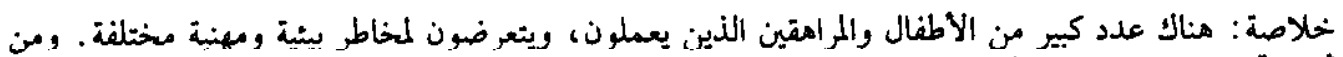

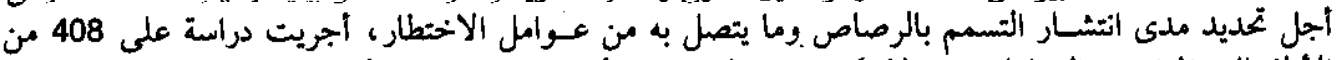

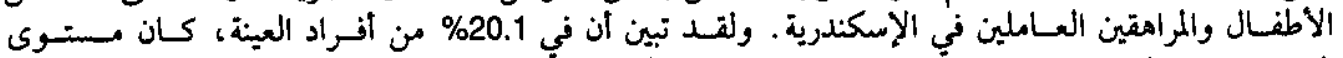

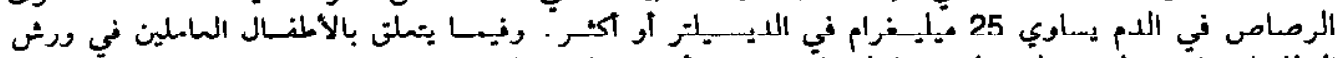

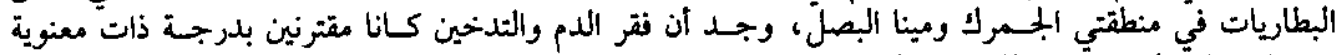

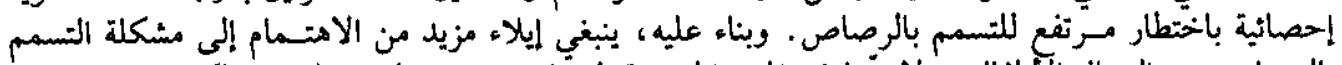

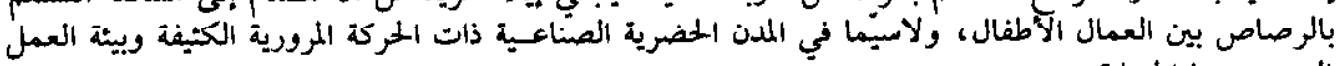

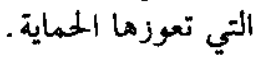

ABSTRACT A substantlal number of children and adolescents work and are exposed to different occupational and environmental hazards. In order to identify the prevalence of lead toxicity and related risk factors, a study was conducted of 408 working children and adolescents in Alexandria. In $20.1 \%$ of those sampled, the blood lead levol was $\geq 25 \mathrm{mg} / \mathrm{dl}$. For children working in battery workshops in El-Gomrouk and Mina El-Bassal districts, anaemia and smoking were found to be significantly associated with a higher risk of lead toxicity. Thus, more attention should be paid to the problem of lead toxicity in working children. particularly in industrialized urban cities with heavy traffic and an unprotected work environment.

\section{Le saturnisme chez les enfants et adolescents qui travaillent à Alexandrie (Egypte)}

RESUME Un grand nombre d'enfants et d'adolescents travaillent et se trouvent exposés à divers risques professionnels et environnementaux. Afin de déterminer la prévalence du saturnisme et les facteurs de risque associés, une étude a été réalisée chez 408 enfants et adolescents qui travaillent à Alexandrle. Parml ceux chez qui des prélèvements ont été effectués, $20,1 \%$ avaient un taux sanguin de plomb égal ou supérieur à $25 \mathrm{mg} / \mathrm{dl}$. Pour les enfants travaillant dans des ateliers de réparation d'accumulateurs dans les quartiers d'El-Gomrouk et Mina El-Bassal, on a constaté que l'anémie et le tabagisme étaient associés de manière significative à un risque plus élevé de sałurnisme. II faut donc accorder plus d'attention au problème du satumisme chez les enfants qui travaillent, en particulier dans les agglomérations urbaines industrialisées où la circulation est intense et le milieu de travail n'est pas protégé.

'Department of Medical Statistics and Clinical Epidemiology, Medical Research Institute; ${ }^{2}$ Department of Occupational Health, High Instifute of Public Health, Alexandria University, Alexandria, Egypt.

'Director-General for Development Cooperation, Italian Embassy, Cairo, Egypt.

Received: 15/2/98; accepled: $22 / 4 / 90$

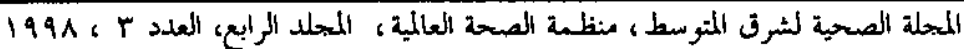




\section{Introduction}

Lead toxicity, one of the most common syndromes of environmental origin, is a challenge to our health care. Yet it should be one of the easiest diseases to eradicate $[1,2]$. The problem becomes more serious among children as they tend to absorb higher amounts of lead than adults [3].

Elevated blood-lead (B-Pb) levels are known to cause a wide range of health problems in infants and children [4-6]. Lead toxicity causes haematological, gastrointestinal and neurological dysfunctions. Excess lead absorption early in life results in decreased cognitive function that persists into late adolescence [7-9]. Recent studies suggest that $\mathrm{B}-\mathrm{Pb}$ levels that were previously considered safe may actually have deleterious effects on several neurobehavioural parameters [10-12]. Furthermore, results from longitudinal studies have shown that the negative effects of lead on cognitive functions persist across cultural and ethnic groups and socioeconomic classes [13].

In October 1991, the Centers for Disease Control and Prevention of the United States Department of Health and Human Services lowered the intervention level for

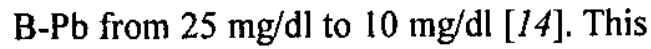
lowering of the designated toxic blood level has significantly increased the number of children who are now considered to suffer from lead poisoning.

The incidence of clinical lead toxicity has been drastically reduced in industrialized countries, while there is a justifiable concern that the problem is of major importance in Egypt and other developing countries [15]. Factors which may elevate $\mathrm{B}-\mathrm{Pb}$ levels include lead in paint, dust, soil and drinking water [16-18]. Lead from folk remedies, cosmetics, food supplements and utensils used for food preparation have caused epidemic and sporadic severe lead toxicity [18].

Alexandria Governorate is an industrial centre with a number of large factories on the outskirts of the city and several workshops dispersed in the urban areas. It suffers from intense traffic activity, with 271 million litres of petrol sold annually for vehicle use alone [19].

Child labour is mostly used in small workshops, which are more difficult to monitor than large factories. The percentage of children in the Egyptian labour force has been estimated to be $12 \%$ and economically active children represent $6.5 \%$ of the population for the age group 6-14 years [20]. The risk of lead toxicity in these children has not been evaluated before.

This study was conducted to estimate the frequency of lead toxicity among working children in Alexandria and to study the potential risk factors affecting lead toxicity in these children.

\section{Subjects and methods}

A cross-sectional study was carried out from September to December 1997 involving children and adolescents under 18 years of age working in different workshops in Alexandria, Egypt.

Alexandria Governorate is divided into 14 districts. In each, there is an industrialized area where most of the workshops are located. Three to five workshops were selected randomly from each of these areas. Children and adolescents $(<18$ years) working in the selected workshops were enrolled in the study. Abbis (representing a rural village), and Amria (representing a desert area) were also included in the study. 
Informed consent to participate in the study was obtained from the child and the employer. A pre-tested questionnaire was used to collect data on demographic factors, socioeconomic status (including detailed housing conditions), personal and dietary habits, and employment details (e.g. age at starting work, type and duration of work). The presence of household facilities was indicated by the availability of water, a power supply and a family latrine or toilet; the absence of any of the three denotes a shortage in household facilities.

Kato-Katz thick-smear technique for stool analysis was used to diagnose intestinal helminths. Haemoglobin levels were measured by the cyanmet-haemoglobin method and packed cell volume using micro-scale capillary tubes. The children were considered anaemic if their haemoglobin (Hb) level was $\leq 12 \mathrm{~g} / \mathrm{dl}$. B-Pb levels were estimated by atomic absorption spectrophotometry using venous blood samples. $\mathrm{B}-\mathrm{Pb}$ levels $\geq 25 \mu \mathrm{g} / \mathrm{dl}$ were considered to indicate lead toxicity. Anti-helminthic drugs and tonics were given free to those found to have intestinal helminths after laboratory investigations.

\section{Statistical analysis}

Data were analysed using SPSS (version 6). Bivariate association between the frequency of lead toxicity and different related factors was tested using the unadjusted odds ratios (OR) with $95 \%$ confidence intervals $(95 \% \mathrm{CI})$. When more than two levels of a variable were considered, $\chi^{2}$ for trend among the different levels was applied. Multiple regression analysis was used to examine the relationship between $\mathrm{B}-\mathrm{Pb}$ level (dependent variable) and other quantitative explanatory variables. To identify signiticant predictors of lead toxicity while adjusting for all potential confounding effects of different covariables, a multiple lo- gistic regression analysis with stepwise variable selection was applied.

The variable category with lowest frequency of lead toxicity was considered as a reference group ${ }^{(\mathrm{R})}$. The following variables were entered into the logistic regression analysis: age in years $\left(<12^{(\mathrm{R})}, 12-, \geq 15\right)$; residence (Nadi El-Seid ${ }^{(R)}$, El-Gomrouk, Mina El-Bassal, El-Labban, Abbis, Amria, Ezbet El-Matar, others); household facilities in house (absent ${ }^{(R)}$, present); renovation of house with oil paint (no ${ }^{(R)}$, yes); smoking (no $^{(\mathrm{R})}$, yes); drinking tea (no ${ }^{(\mathrm{R})}$, yes); tea taken after a meal (never ${ }^{(R)}$, sometimes, usually); Hb level (>12 $\left.\mathrm{g} / \mathrm{dl}^{(\mathrm{R})}, \leq 12 \mathrm{~g} / \mathrm{dl}\right)$; intestinal helminths (no ${ }^{(\mathrm{k})}$, yes); occupation of the longest duration (carpentry ${ }^{(R)}$, metal work, battery shops, others); total duration of work in months $\left(<6^{(\mathrm{k})}, 6-12,>12\right)$; place of work (Nadi El-Seid(R), El-Gomrouk, Mina El-Bassal, El-Labban, Abbis, Amria, Ezbet El-Matar, others). The significant level for covariates entering and remaining in the logistic model was $10 \%$. The association between exposures and outcome are expressed in terms of OR together with their $95 \% \mathrm{CI}$.

\section{Results}

The study was carried out on 408 working children and adolescents in Alexandria Governorate. Their ages ranged from 7 years to 18 years with a mean of $13.5 \pm 2.3$ years. Age at starting work was under 12 years in $46.1 \%$ of children; only $9.6 \%$ started working at or above the age of 15 years. Twenty-two per cent ( $22 \%$ ) of the 408 children and adolescents studied were living in houses lacking one or more of the basic household facilities. Crowding index (number of persons per room) was $1-3$ in $42.3 \%$ of cases, $4-6$ in $44.8 \%$ and $>7$ in $12.9 \%$. 


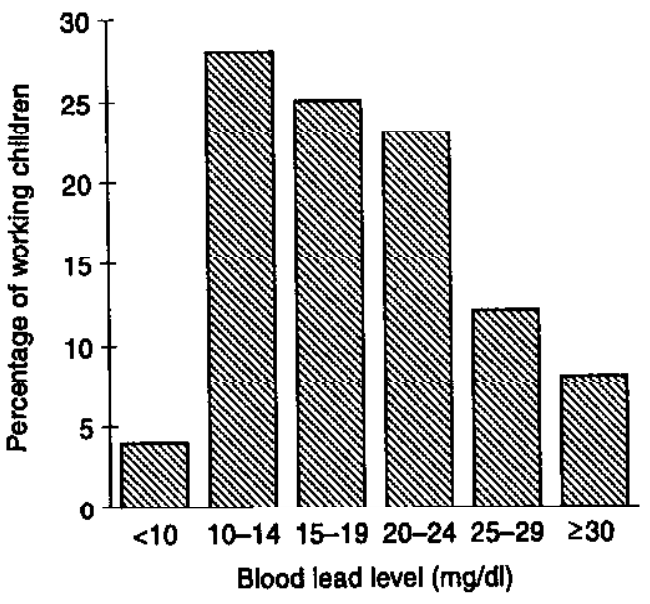

Figure 1 Blood lead level in working children
Figure 1 shows the distribution of $\mathrm{B}-\mathrm{Pb}$ levels in the sample studied. B-Pb levels ranged from $8 \mu \mathrm{g} / \mathrm{d}$ l to $42 \mathrm{mg} / \mathrm{dl}(=18.8 \pm$ $6.9 \mathrm{mg} / \mathrm{dl}$ ). In $96 \%$ of the children examined, the $\mathrm{B}-\mathrm{Pb}$ level was $\geq 10 \mathrm{mg} / \mathrm{dl}$ and in $20 \%$ it was $\geq 25 \mathrm{mg} / \mathrm{dl}$.

The relation between sociodemographic characteristics and lead toxicity is shown in Table 1. No significant increase in the risk of lead toxicity (B-Pb $\geq 25 \mathrm{mg} / \mathrm{dl}$ ) was related to age, availability of household facilities or recent renovation of the house with oil paint. Considering the district with lowest frequency of lead toxicity as a reference category, children living in El-Gomrouk $(\mathrm{OR}=14.4,95 \%$ CI $4.3-50.0)$ and Mina

Table 1 Distribution of working children according to sociodemographic characteristics: cases presenting with lead toxicity (82) and those without (326)

\begin{tabular}{|c|c|c|c|c|c|c|c|}
\hline \multirow[t]{3}{*}{ Variable } & \multicolumn{4}{|c|}{ Lead toxicity" } & \multirow[t]{3}{*}{ Total } & \multirow[t]{3}{*}{ OR } & \multirow[t]{3}{*}{$95 \% \mathrm{Cl}$} \\
\hline & \multicolumn{2}{|c|}{ Yes } & \multicolumn{2}{|c|}{ No } & & & \\
\hline & No. & $\%$ & No. & $\%$ & & & \\
\hline \multicolumn{8}{|l|}{ Age (years) } \\
\hline$<12(A)$ & 14 & 17.5 & 66 & 82.5 & 80 & 1.0 & \\
\hline $12-$ & 37 & 20.7 & 142 & 79.3 & 179 & 1.2 & $0.6-2.6$ \\
\hline 15 and over & 31 & 20.8 & 118 & 79.2 & 149 & 1.2 & $0.6-2.7$ \\
\hline \multicolumn{8}{|l|}{ Residence (district) } \\
\hline Nadi El-Seid ${ }^{(\mathrm{A})}$ & 8 & 8.9 & 82 & 91.1 & 90 & 1.0 & \\
\hline El-Gomrouk & 14 & 58.3 & 10 & 41.7 & 24 & 14.4 & $4.3-50.0^{b}$ \\
\hline Mina El-Bassal & 21 & 30.4 & 48 & 69.6 & 69 & 4.5 & $1.7-2.0^{\mathrm{b}}$ \\
\hline El-Labban & 4 & 16.0 & 21 & 84.0 & 25 & 1.9 & $0.4-8.2$ \\
\hline Abbis & 6 & 18.2 & 27 & 81.8 & 33 & 2.3 & $0.6-8.1$ \\
\hline Amria & 11 & 15.9 & 58 & 84.1 & 69 & 1.9 & $0.7-5.7$ \\
\hline Ezbet El-Matar & 6 & 15.8 & 32 & 04.2 & 30 & 1.0 & $0.5-6.7$ \\
\hline Others & 12 & 20.7 & 46 & 79.3 & 58 & 2.7 & $0.9-7.8$ \\
\hline \multicolumn{8}{|l|}{ Household facilities } \\
\hline Absentidis & 14 & 15.4 & 77 & 84.6 & 01 & 1.0 & \\
\hline Present & 68 & 21.6 & 247 & 78.4 & 315 & 1.5 & $0.8-3.0$ \\
\hline \multicolumn{8}{|c|}{ Renovation of house with oil paint } \\
\hline $\mathrm{No}^{(\mathrm{A})}$ & 72 & 10.7 & 293 & 80.3 & 365 & 1.0 & \\
\hline Yes & 10 & 24.4 & 31 & 75.6 & 41 & 1.3 & $0.6-3.0$ \\
\hline $\begin{array}{l}\text { Blood lead level } \geq 25 \mu \mathrm{g} / \mathrm{dl} \\
\mathrm{OH}=\text { Oods rato }\end{array}$ & $a t=c$ & ${ }^{\circ} \mathrm{P}<0.0$ & & (n) $=A e r$ & caltgoiry & & \\
\hline
\end{tabular}

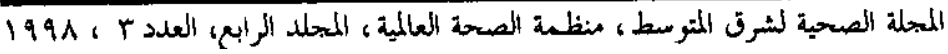


Table 2 Personal habits and clinical characteristics of working children: cases presenting with lead toxicity (82) and those without (326)

\begin{tabular}{|c|c|c|c|c|c|c|c|}
\hline \multirow[t]{3}{*}{ Variable } & \multicolumn{4}{|c|}{ Lead toxicity } & \multirow[t]{3}{*}{ Total } & \multirow[t]{3}{*}{ OR } & \multirow[t]{3}{*}{$95 \% \mathrm{Cl}$} \\
\hline & \multicolumn{2}{|c|}{ Yes } & \multicolumn{2}{|c|}{ No } & & & \\
\hline & No. & $\%$ & No. & $\%$ & & & \\
\hline \multicolumn{8}{|l|}{ Smoking } \\
\hline $\mathrm{No}^{(\mathrm{R})}$ & 73 & 19.2 & 308 & 80.8 & 381 & 1.0 & \\
\hline Yes & 9 & 33.3 & 18 & 66.7 & 27 & 2.1 & $0.8-5.2$ \\
\hline \multicolumn{8}{|l|}{ Drinking of tea } \\
\hline $\mathrm{No}^{(\mathrm{P})}$ & 8 & 15.1 & 45 & 84.9 & 53 & 1.0 & \\
\hline Yes & 74 & 20.8 & 281 & 79.2 & 355 & 1.5 & $0.6-3.6$ \\
\hline \multicolumn{8}{|c|}{ Tea after meals } \\
\hline Never(f) & 12 & 16.7 & 60 & 83.3 & 72 & 1.0 & \\
\hline Sometimes & 5 & 17.2 & 24 & 82.8 & 29 & 1.0 & $0.3-3.7$ \\
\hline Usually & 65 & 21.2 & 242 & 78.8 & 307 & 1.3 & $0.7-2.8$ \\
\hline \multicolumn{8}{|l|}{ Hb level $(g / d)$} \\
\hline$>12^{(\mathrm{f})}$ & 50 & 19.3 & 209 & 80.7 & 259 & 1.0 & \\
\hline$\leq 12$ & 32 & 21.5 & 117 & 78.5 & 149 & 1.1 & $0.7-1.9$ \\
\hline \multicolumn{8}{|c|}{ Intestinal helminths } \\
\hline $\mathrm{No}^{(\mathrm{P})}$ & 30 & 17.2 & 144 & 82.8 & 174 & 1.0 & \\
\hline Yes & 52 & 22.2 & 182 & 77.8 & 234 & 1.4 & $0.8-2.3$ \\
\hline \multicolumn{8}{|c|}{ No. of parasites } \\
\hline Free $e^{\left(P^{\prime}\right)}$ & 30 & 172 & 144 & 82.8 & 174 & 1.0 & \\
\hline Single & 37 & 21.9 & 132 & 78.1 & 169 & 1.4 & $0.8-2.4$ \\
\hline Multiple & 15 & 23.1 & 50 & 76.9 & 65 & 1.3 & $0.8-2.3$ \\
\hline \multicolumn{8}{|c|}{$\left(x^{2}\right.$ for trend $\left.=1.4 . P=0.23\right)$} \\
\hline
\end{tabular}

El-Bassal $(\mathrm{OR}=4.5,95 \% \mathrm{Cl} 1.7-12.0)$ were at the highest risk of lead toxicity.

Table 2 sets out the relation between personal habits and lead toxicity. Smoking and drinking tea show some increased risk of lead toxicity (yet statistically non-significant). Considering clinical characteristics, lead toxicity was somewhat more frequently encountered in children with $\mathrm{Hb} \leq 12 \mathrm{~g} /$ dl (21.5\% of subjects) than in those with $\mathrm{Hb}$ levels $>12 \mathrm{~g} / \mathrm{dl}$ (19.3\% of subjects). Also lead toxicity was more frequent in children suffering from intestinal helminths
$(22.2 \%)$ than helminth-free children $(17.2 \%)$.

Occupation-related factors and their impact on the risk of lead toxicity are shown in Table 3. Lead toxicity was more frequently encountered in children working in battery shops $(38.5 \%)$. Considering the total duration of work, lead toxicity was less frequent (14.3\%) among children who had worked for less than 6 months as compared with those who had worked for longer periods $(20.8 \%$ and $21.4 \%)$. The place of work was significantly associated with lead tox- 
Table 3 Distribution of working children according to occupation-related factors: cases presenting with lead toxicity (82) and those without (326)

\begin{tabular}{|c|c|c|c|c|c|c|c|}
\hline \multirow[t]{3}{*}{ Variable } & \multicolumn{4}{|c|}{ Lead toxicity } & \multirow[t]{3}{*}{ Total } & \multirow[t]{3}{*}{ OR } & \multirow[t]{3}{*}{$95 \% \mathrm{Cl}$} \\
\hline & \multicolumn{2}{|c|}{ Yes } & \multicolumn{2}{|c|}{ No } & & & \\
\hline & No. & $\%$ & No. & $\%$ & & & \\
\hline \multicolumn{8}{|c|}{ Occupation of the longest duration } \\
\hline Carpenter ${ }^{(\mathrm{A})}$ & 1 & 7.1 & 13 & 92.9 & 14 & 1.0 & \\
\hline Battery shop worker & 5 & 38.5 & 8 & 61.5 & 13 & 5.4 & $0.7-40.2$ \\
\hline Others & 16 & 23.5 & 52 & 76.5 & 68 & 3.3 & $0.5-22.9$ \\
\hline Metal worker & 18 & 23.1 & 60 & 76.9 & 78 & 3.2 & $0.5-22.3$ \\
\hline Car services worker & 42 & 17.9 & 193 & 82.1 & 235 & 2.5 & $0.4-16.9$ \\
\hline \multicolumn{8}{|c|}{ Total duration of work (months) } \\
\hline$<6^{(\mathrm{F})}$ & 10 & 14.3 & 60 & 85.7 & 70 & 1.0 & \\
\hline $6-12$ & 10 & 20.8 & 38 & 79.2 & 48 & 1.6 & $0.5-4.6$ \\
\hline$>12$ & 62 & 21.4 & 228 & 78.6 & 290 & 1.6 & $0.8-3.6$ \\
\hline \multicolumn{8}{|c|}{$\left(\chi^{2}\right.$ for trend $\left.=1.56, P=0.21\right)$} \\
\hline \multicolumn{8}{|l|}{ Place of work } \\
\hline Nadi El-Seid(P) & 7 & 7.5 & 86 & 92.5 & 93 & 1.0 & \\
\hline $\begin{array}{l}\text { El-Gomrouk } \\
\text { Mina El-Bassal }\end{array}$ & $\begin{array}{l}17 \\
17\end{array}$ & $\begin{array}{l}54.8 \\
32.7\end{array}$ & $\begin{array}{l}14 \\
35\end{array}$ & $\begin{array}{l}45.2 \\
67.3\end{array}$ & $\begin{array}{l}31 \\
52\end{array}$ & $\begin{array}{r}14.9 \\
6.0\end{array}$ & $\begin{array}{l}4.7-49.1^{b} \\
2.0-17.6^{\circ}\end{array}$ \\
\hline El-Labban & 16 & 27.6 & 42 & 72.4 & 58 & 4.7 & $1.6-13.7^{b}$ \\
\hline Abbis & 6 & 18.2 & 27 & 81.8 & 33 & 2.7 & $0.7-10.1$ \\
\hline Amrla & 10 & 14.9 & 57 & 65.1 & 67 & 2.2 & $0.7-0.7$ \\
\hline Ezbet El-Matar & 6 & 13.3 & 39 & 86.7 & 45 & 1.9 & $0.5-6.8$ \\
\hline Others & 3 & 10.3 & 26 & 89.7 & 29 & 1.4 & $0.3-6.7$ \\
\hline
\end{tabular}

Blood lead level $\geq 25 \mu \mathrm{g} / \mathrm{dl} \quad 0.05$

$\mathrm{OR}=$ odds ratio $\quad \mathrm{Cl}=$ confidence interval $\quad$ a fieference category

icity and higher risks were seen in children working in El-Gomrouk (OR $=14.9,95 \%$ Cl 4.7-49.1), Mina El-Bassal (OR - 6.0, 95\% Cl 2.0-17.6) and El-Labban (OR = $4.7,95 \% \mathrm{Cl} 1.6-13.7$ ) (Table 3 ).

After adjusting for other potential confounders with regard to personal habits, only smoking was found to be a significant predictor of lead toxicity (Table 4). Allowing for other variables in the logistic model with regard to clinical characteristics, only a $\mathrm{Hb}$ level $\leq 12 \mathrm{~g} / \mathrm{dl}$ was a significant predictor of lead toxicity. Adjusting for other potential confounders, children working in battery shops, and those working in El-Gio- mrouk and Mina El-Bassal were at a higher risk of lead toxicity.

Using the multiple regression model to study the relation between $\mathrm{B}-\mathrm{Pb}$ level and other continuous variables, only the $\mathrm{Hb}$ level and the number of cigarettes smoked per day were significantly related to the lead level (Table 5).

\section{Discussion}

The findings of this study strongly illustrate the public health importance of lead toxicity among this group of childrert. The fre- 
Table 4 Predictors of lead toxicity (logistic regression analysis)

\begin{tabular}{|c|c|c|}
\hline Covariate & OR & $95 \% \mathrm{Cl}$ \\
\hline \multicolumn{3}{|l|}{ Occupation } \\
\hline Carpenter $r^{(M)}$ & 1.0 & \\
\hline Battery shop worker & 23.8 & $1.4-408.3^{a}$ \\
\hline Metal worker & 3.3 & $0.7-39.2$ \\
\hline Car services worker & 2.1 & $0.2-24.3$ \\
\hline Others & 3.5 & $0.3-44.6$ \\
\hline \multicolumn{3}{|l|}{ Place of work } \\
\hline Ezbel El-Matar(f) & 1.0 & \\
\hline El-Gomrouk & 7.5 & $1.6-34.4^{\mathrm{a}}$ \\
\hline Mina El-Bassal & 5.0 & $1.1-23.8^{\mathrm{a}}$ \\
\hline El-Labban & 3.5 & $0.7-17.1$ \\
\hline Abbis & 2.7 & $0.2-39.5$ \\
\hline Amria & 1.7 & $0.4-8.5$ \\
\hline Nadi El-Seid & 0.9 & $0.2-4.2$ \\
\hline \multicolumn{3}{|l|}{ Hb level $(g / d l)$} \\
\hline$>12^{(\mathrm{i})}$ & 1.0 & \\
\hline$\leq 12$ & 2.1 & $1.1-4.0^{a}$ \\
\hline \multicolumn{3}{|l|}{ Smoking } \\
\hline $\mathrm{No}^{(\mathrm{fi})}$ & 1.0 & \\
\hline Yes & 1.2 & $1.1-1.3^{3}$ \\
\hline
\end{tabular}

Factors included in the model were: age, residence, household facilities, renovation of house with oil paint. tvpe of work. place of work, total duration of work, smoking, drinking tea, anaemia and intestinal helminths.

* $P<0.05$

$H b=$ haemoglobin

Table 5 Prodictore of blood lead levels (multiple regression analysis)

\begin{tabular}{lcc}
\hline Variable & $\beta$ & $t$ \\
\hline Haemoglobin & -0.18 & $2.44^{\mathrm{a}}$ \\
Haematocrit value & -0.01 & 0.17 \\
Ferritin & 0.003 & 0.05 \\
Total ferrous intake & 0.05 & 0.75 \\
Duration of work (months) & -0.02 & 0.24 \\
No. of cigarettes per day & 0.16 & $2.39^{\mathrm{a}}$ \\
No. of cups of tea per day & 0.04 & 0.58 \\
\hline
\end{tabular}

quency of lead toxicity among working children and adolescents in Alexandria Governorate is alarmingly high ( $96.1 \%$ $\geq 10 \mathrm{mg} / \mathrm{dl}$ and $20.1 \% \geq 25 \mathrm{mg} / \mathrm{dl}$ ). The need for action becomes even more urgent if we consider the recummendations of the Centers for Disease Control in October 1991 to lower the intervention level for B-Pb from $25 \mathrm{mg} / \mathrm{dl}$ to $10 \mathrm{mg} / \mathrm{dl}$ [14]. Since exposure to lead is a threat to child health in most industrialized societies, special attention should be given to lead levels in children even marginally higher than those considered safe [2l].

Working children are exposed to multiple sources of lead. Besides the particular hazards of exposure related to the work environment, they are more exposed to street traffic and they consume more street food which has been found to contain higher lead contamination.

The place of work proved to be a significant predictor of lead toxicity. This was to be expected as most of these children spend the majority of their day at work. The higher frequency of lead toxicity among children and adolescents working in El-Gomrouk and Mina El-Bassal should be a subject of detailed study to reveal the possible underlying causes. The heavy traffic noted in these districts could be one of the important causes as virtually all of the petrol used in Alexandria at the time of conducting this study contained lead additives. Approximately $20 \%$ of cars use 90 -octane petrol with $0.9 \mathrm{~g} / \mathrm{l}$ of lead, while $80 \%$ use 80-octane petrol with $0.4 \mathrm{~g} / \mathrm{l}$ of lead. In a previous study in some regions covered in the present study, high levels of lead in the air were found in El-Gomrouk and Mina El-Bassal $\left(0.56 \mathrm{mg} / \mathrm{m}^{3}\right.$ and $0.61 \mathrm{mg} / \mathrm{m}^{3} \mathrm{re}-$ spectively) while a lower lead level was reported in Ezbet El-Matar $\left(0.21 \mathrm{mg} / \mathrm{m}^{3}\right)$ [22]. This coincides with the proportion of 
lead toxicity in the different areas reported in our study.

The relation between malnutrition, parasitic infection and lead toxicity is of interest, particularly in developing countries. Although parasitic infection was associated with a higher (but statistically non-significant) risk of lead toxicity as shown in bivariate antalysis in Table 2, only the $\mathrm{Hb}$ level $\leq 12 \mathrm{~g} / \mathrm{dl}$ was found to be an independent predictor of lead toxicity after adjusting for other cuvariates (Table 4). This was confirmed by the significant inverse linear relation found between $\mathrm{Hb}$ level and $\mathrm{B}-\mathrm{Pb}$ level in the multiple regression model (Table 5). This is supported by Schwartz et al. who found a dose-response relationship between $\mathrm{B}-\mathrm{Pb}$ tevels and haematocrit values in young children [23]. Factors impeding ferrous absorption could enhance lead absorption [24], and the lack of Iron may both exacerbate the effects of excess lead and independently may adversely affect intellectual function [25].

Regarding the relation between smoking and lead toxicity, and in accordance with our results, Grandjean found that increased blood lead concentrations were related to smoking and drinking alcohol [26]. It is difficult to interpret the association between smoking and increased lead levels, but it may be attributed to the ingestion of lead (contamination from hands during work) or increased absorption of inhaled lcad in smokers.

Battery workshops and other work places where there is a high risk of lead toxicity should be under strict supervision to prohibit (or limit) the involvement of children in such work.

In conclusion, more attention to the problem of lead toxicity in working children and adolescents living in developing countrics is warranted, particularly in industrialized urban cities with heavy traffic and unprotected work environments.

\section{Acknowledgements}

This work was supported by Consorzio di Medicina Tropicale (CMT), Italy through the project of extension of the Mcdical Rcsearch Institute, Alexandria University, Egypt. We are grateful to Professor Shehata El-Sewedy, Dean of the Medical Research Institute, Alexandria University and Professor Giovanni Rocchi, Director of the Public Health Department, University of Tor Vergata, Rome, Italy for their assistance. We thank Dr Claudia Gandin, Coordinator of CMT for her help and support and Dr M. El-Shamy for his efforts in carrying out the laboratory investigations.

\section{References}

1. Needleman HL. Preventing childhood lead toxicity. Preventive medicine, 1994, 23(5):634-7.

2. Needham DD. Diagnosis and management of lead-poisoned children: the pediatric nurse practitioner in a speciality program. Joumal of pediatric health care, 1994, 8(6):268-73.
3. Alexander $F$. The uptake of lead by chilaren in aifferent environments. Environmental health perspective, 1974, 7:155-60.

4. Piomelli $S$ et al. Threshold for lead damage to heme synthesis in urban children. Proceedings of the National Academy of 
Sciences of the United States of America, 1982, 79:3335-9.

5. Hernberg S, Nikkman J. Enzyme inhibition by lead under normal urban conditions. Lancet, 1970, 1(7637):63-4.

6. Rutter M. Raised lead levels and impaired cognitive/behavioural functioning: a review of the evidence. Developmental medicine and child neurology, 1980, 22 (suppl. 42):1-36.

7. Baghurst $P$ et al. Environmental exposure to lead and children's intelligence at the age of seven years: the Port Pirie Cohort Study. New England journal of medicine, 1992, 327:1279-84.

8. Bellinger DC, Stiles KM, Needleman HL. Low-level lead exposure, intelligence and academic achievement: a long-term follow-up study. Pediatrics, 1992, 90:855-61.

9. Needleman HL et al. The long-term effects of exposure to low doses of lead in childhood. An 11-year follow-up report. New England journal of medicine, 1990 . 322:83-8.

10. Schwartz J, Otto D. Blood lead. hearing thresholds and neurobehavioral development in children and youth. Archives of environmental health, 1987, 42:153-60.

11. Fulton $\mathrm{M}$ et al. Influence of blood lead on the ability and attainment of children in Edinburgh. Lancet, 1987, 1(8544):12216.

12. Bellinger $D$ et al. Low-level lead exposure and childron's cognitive function in the preschool years. Pediatrics, 1991, 87:219-27.

13. Manaffey $\kappa$. Exposure to lead in childhood. New England joumal of medicine, 1992, 327:1308-9.

14. Centers for Disease Control and Prevention. Preventing lead poisoning in young children: a statement by the Centers for DIsease Control and Prevention, Atlanta,
Georgia. Rockville, Maryland, Government Institutes Incorporated, 1991.

15. Mahaffey KR. Nutrition and lead strategies for public health. Environmental health perspective, 1995, 103 (suppl. 6):191-6.

16. Mushak $P$, Crocetti AF. Determination of numbers of lead-exposed American children as a function of lead source: Integrated summary of a report to the US Congress on childhood lead poisoning. Environmental research, 1089 , $50(2): 210-29$.

17. Schwartz J, Levin R. The risk of lead toxIclty In homes with lead paint hazard. Environmental research, 1991, 54(1):1-7.

18. Lockitch $\mathrm{G}$. Prescriptives on lead toxicity. Clinical biochemistry, 1993, 26(5):37181.

19. General Petroleum Agency. Annual report. Cairo, Egypt, General Petroleum Agency, 1996.

20. Amin T. Health problems among young workers in small and medium size industries. [Doctoral thesis]. Alexandria, Egypt. High Institute of Public Health, Al. exandria University, 1992:93.

21. Shen $X M$ et al. The adverse effect of marginally higher lead levels on intelligence development of children: a Shanghai study. Indian journal of pedriatrics, 1992, 59(2):233-8.

22. El-Sharkawy M. The assessment of tratfic air pollution in the city of Alexandria. [Doctoral thesis]. Alexandria, Egypt, High Institute of Public Health, Alexandria University, 1993:65.

23. Schwartz $\mathrm{J}$ et al. Lead-induced anemia: dose-response relationships and evidence for a threshold. American journal of public health, 1990, 80(2):165-8.

24. Carraccio CL, Bergman GE, Daley BP. Combined iron deficiency and lead poi- 
soning in children. Effect on FEP levels. Clinical pediatrics, 1987, 26(12):644-7.

25. Wasserman $G$ el al. Independent elfects of lead exposure and iron deficiency anemia on development outcome at age 2 years. Journal of pediatrics, 1992, 121:695-703.

26. Grandjean P. International perspectives of lead exposure and lead toxicity. Neurotoxicology, 1993, 14(2-3):9-14.

\section{Protection and promotion of occupational health}

Avallable statistical data on occupational health and work safety in countrles of the Eastern Mediterranean Reglon, with particular reference to morbidity and mortality from disease and accidents attributed to working conditions, remain scanty and grossly underestimate the magnitude of the problem. Information on specialized health personnel rendering services to workers in manufacturing, agriculture, construction, mines and small-scale factories is also incomplete. Efforts are Deing exerted Dy many Member States in collaboration with WHO to fill this gap.

During 1997, as part of natlonal efforts to develop and strengthen national programmes on occupational health and work safety, the Reglonal Office collaborated with some countrles in the conduct of national situation analyses to obtain rellable information on mortality and morbidity patterns of workers of different categories and at organized and unorganized work sites in order to formulate approprlate national strategies which would respond to the local needs.

In order to assist countries of the Region in their efforts to Introduce occupational health services into thelr national primary health care systems, the Reglonal Office held an intercountry consultation for development of a training course for community health workers in occupational health in 1997. The consultation outlined a tralning framework that would enable community health workers to recognize most common hazards in the workplace, create the know-how for controlling them and use the support available to them for referral and medical consultation. As a result. a model training manual is now heing prepared in the Reglonal Office and is expected to be available to countrles of the Region in 1998.

Source: The Work of WHO in the Eastern Mediterranean Region. Annual Report of the Regional Director I January-31 December 1997, page 73. 